\title{
Prevalence of Maternal Anemia in A Tertiary Care Hospital in Western Nepal
}

\author{
Anita Lamichhane, ${ }^{1}$ Sharmila Gurung, ${ }^{2}$ Kiran Panthee, ${ }^{3}$ Deekshya Shrestha ${ }^{4}$ \\ 'Department of Pediatrics, Lumbini Medical College, Pravas, Palpa, Nepal, ${ }^{2}$ Department of Forensic Medicine, Devdaha \\ Medical College,Bhaluhi, Rupandehi, Nepal, ${ }^{3}$ Department of Pediatrics, Devdaha Medical College, Bhaluhi, Rupandehi, \\ Nepal, ${ }^{4}$ Department of Obstetrics \& Gynaecology, Devdaha Medical College, Bhaluhi, Rupandehi, Nepal.
}

\section{ABSTRACT}

Introduction: Maternal anemia is a common problem in developing countries like Nepal accounting for around $30-50 \%$ of women becoming anemic during pregnancy. The present study aims to find out the prevalence of maternal anemia in a tertiary care hospital in Western Nepal.

Methods: A descriptive cross-sectional study was carried out at Devdaha Medical College, Bhaluhi, Rupandehi, Nepal from October 2018 to May 2019 after taking ethical approval from the institutional review committee with the approval number: 012/2018. Three eighty three samples were taken and convenient sampling was done to reach the sample size. Data were collected from the study population after taking consent and entered in a predesigned proforma. It was then entered in an SPSS; point estimate at 95\% CI was calculated along with frequency and proportion for binary data.

Results: During the study period, out of 383 mothers, 230 (60.2\%) mothers were anemic at 95\% CI (10.6-10.8\%); of which 172 (74.8\%) were moderately anemic while 58 (25.2\%) were mild anemic. The mean maternal Haemoglobin was 9.5 $\pm 1.76 S D$. The mean maternal age was $24.24 \pm 3.26$ SD; mean gestational age at the time of delivery was $36.08 \pm 1.77$ SD.

Conclusions: The prevalence of maternal anemia in this study is found to be higher than the national data which implies that maternal anemia is still a public health issue which needs to be addressed in spite of safe motherhood program launched by the government of Nepal.

Keywords: maternal anemia; pregnancy; safe motherhood.

\section{INTRODUCTION}

Maternal anemia, in developing countries like Nepal is the most common medical condition accounting for around $30-50 \%$ of women becoming anemic during pregnancy.' WHO defines anemia as haemoglobin $<11$ grams $\%$ in pregnancy, mild anemia (10-10.9 g/dL), moderate anemia $(7-9.9 \mathrm{~g} / \mathrm{dL})$ and severe anemia $(<7 \mathrm{~g} / \mathrm{dL}) .{ }^{2,3}$ Globally, about $38.2 \%$ of pregnant mothers are anemic. ${ }^{4}$ Nepal Demographic Health Survey (2011) shows the prevalence rate of anemia in pregnancy to be $48 \% .^{5}$

Maternal anemia is associated with Post-Partum
Haemorrhage (PPH), Low Birth Weight (LBW) babies, prematurity, Small for Gestational Age (SGA) babies and perinatal death. This gestational outcome is considered as a major public health concern; it is more prevalent in countries with low financial resources. ${ }^{6}$ LBW (weight $<2500$ grams) are more prone to infant morbidity and mortality. ${ }^{7}$

Correspondence: Dr. Anita Lamichhane, Department of Pediatrics, Lumbini Medical College and Teaching Hospital, Pravas, Palpa, Nepal. Email: anitalamee@gmail.com, Phone: +977-9843359884. 
The objective of the study was to find the prevalence of maternal anemia in a tertiary care hospital in Western Nepal.

\section{METHODS}

This hospital-based descriptive cross-sectional study was conducted from October 2018 to May 2019 at Devdaha Medical College, Bhaluhi, Rupandehi, Nepal after taking ethical approval from the institutional review committee (IRC) of the college. The present study included 383 pregnant mothers $>18$ years of age with ANC visits done at Devdaha Medical College with a singleton pregnancy using consecutive sampling method. Those pregnant women with multiple pregnancies, history of preterm delivery and with any obstetrical complications or medical illness except anemia were excluded from the study. We took a written consent from the mother to participate in the study for the mothers. A detailed history was taken from the mother during the presentation for delivery and the data of the mothers was entered in the predesigned proforma. The blood of the mothers were collected from the antecubital vein and stored in the EDTA containing vial and then analysed using the automated hematologic analyzer.

Maternal anemia was defined as $\mathrm{Hb}<11 \mathrm{~g} / \mathrm{L}$. All the information including gestational age at the time of delivery, mode of delivery, clinical signs and symptoms, indication for admission in NICU, maternal risk factors, were recorded in the predesigned proforma. The perinatal outcome was defined as the maternal and fetal consequences caused by maternal habits and pregnancy complications during labor and one hour after delivery. The maternal consequences included preterm delivery, prolonged labor and maternal mortality whereas fetal consequences included small for gestational age, low Apgar score, intrauterine growth retardation, and intrauterine death. The fetal outcomes were small for gestational age, congenital anomalies, low birth weight, stillbirth, respiratory distress syndrome, preterm babies, intrauterine growth retardation, low Apgar score less than 5 at $1 \mathrm{~min}$ and birth asphyxia.

Convenient sampling was done and the sample size was calculated using the formula, ${ }^{8}$

$$
\begin{aligned}
& \text { Sample size } \begin{aligned}
& Z^{2} \times p q / d^{2} \\
& =3.84 \times 0.48 \times 0.48 /(0.05)^{2} \\
& =383
\end{aligned} \\
& Z=1.96 \text { at } 95 \% \mathrm{Cl} . \\
& p=\text { prevalence of maternal anemia, } 48 \%{ }^{6} \\
& q=1-p
\end{aligned}
$$

$$
e=\text { margin of error, } 5 \%
$$

The total sample size calculated was 383 .

The mothers were followed until discharge or death. In case of death, the cause of mortality was recorded. Data were checked for any errors or inconsistencies, then entered in a Statistical Package for Social Sciences (SPSS), point estimate at $95 \% \mathrm{Cl}$ was calculated along with frequency and proportion for binary data.

\section{RESULTS}

The prevalence of maternal anemia was found out to be $60.2 \%$ at $95 \% \mathrm{Cl}(10.6-10.8 \%)$ in our study. During the study period, 383 mothers and their newborn babies were evaluated. Out of them, 230 (60.2\%) mothers were anemic; of which 172 (74.8\%) were moderately anemic while 58 (25.2\%) were mild anemic. No one was found to be severely anemic. The mean maternal Haemoglobin was 9.5 \pm 1.76 SD. There were 366 (95.5\%) live-born, stillbirth 03 (0.8\%) and IUFD 14 (3.7\%) babies. The mean maternal age was $24.24 \pm 3.26 \mathrm{SD}$, (range $=16$-38 years, median $=24.00$ ); mean gestational age at the time of delivery was $36.08 \pm 1.77 \mathrm{SD}$. The mean birth weight of the baby was $2.35 \pm 0.374 \mathrm{~kg}$. Male: female ratio was 1.4:1.Perinatal mortality in our study was 44.3 per thousand population. In mothers with anemia, low birth weight was seen in $161(42.0 \%)$ at $95 \% \mathrm{Cl}(2.31$ 2.38) cases and most of the mothers were from rural area $261(68.1 \%)$. The demographic characteristics of our study population are depicted (Table 1).

\begin{tabular}{|ll|}
\hline $\begin{array}{l}\text { Table 1. Showing demographic characteristics of the } \\
\text { study population. }\end{array}$ \\
\hline Characteristics \\
Outcome \\
Live born \\
Stillbirth & $366(95.5)$ \\
IUFD & $03(0.8)$ \\
Mode of delivery & $14(3.7)$ \\
Normal delivery & \\
Caesarean & $183(47.8)$ \\
Vacuum & $171(44.6)$ \\
Place of residence & $29(7.6)$ \\
Urban & $122(31.9)$ \\
Rural & $261(68.1)$ \\
Sex & \\
Male & $224(54.49)$ \\
Female & $158(41.25)$ \\
Ambiguous genitalia & $01(0.26)$ \\
Anemia in mother &
\end{tabular}


Lamichhane et al. Prevalence of Maternal Anemia in A Tertiary Care Hospital in Western Nepal

$\begin{array}{|ll|}\text { Present } & 213(55.61) \\ \text { Absent } & 170(44.39) \\ \text { Term delivery } \geq 37 \text { weeks) } & 162(42.3) \\ \text { Preterm delivery }<37 \text { weeks) } & 221(57.7) \\ \text { Maternal death } & \\ \text { Yes } & 01(0.3) \\ \text { No } & 382(99.7) \\ \text { Early neonatal death } & \\ \text { Yes } & 03(0.8) \\ \text { No } & 380(99.2) \\ \text { Admission in NICU } & 318(83) \\ \text { No } & 65(17) \\ \text { Yes } & \\ \text { Anemia in baby } & 25(6.5) \\ \text { Yes } & 358(93.5) \\ \text { No } & \\ \text { Congenital anomalies } & 372(97) \\ \text { Absent } & 11(2.9) \\ \text { present } & \end{array}$

Among anemic mothers, anemia was found prevalent at 37 weeks of gestation following second most at 35 and 36 weeks respectively (Table 2 ).

\begin{tabular}{|c|c|c|}
\hline \multicolumn{3}{|c|}{$\begin{array}{l}\text { Table 2. Showing the relationship between } \\
\text { maternal anemia and gestational age at delivery. }\end{array}$} \\
\hline \multirow{2}{*}{$\begin{array}{l}\text { Gestational } \\
\text { age (weeks) }\end{array}$} & \multicolumn{2}{|c|}{ Anemia in mother } \\
\hline & Yes n (\%) & No n (\%) \\
\hline 32 & $7(1.82)$ & $00(0)$ \\
\hline 33 & $14(3.7)$ & $04(2.6)$ \\
\hline 34 & $27(7.0)$ & 25 (16.3) \\
\hline 35 & $45(11.7)$ & $40(26.1)$ \\
\hline 36 & $37(9.7)$ & $22(14.4)$ \\
\hline 37 & $54(14.1)$ & $24(15.7)$ \\
\hline 38 & $28(7.3)$ & $19(12.4)$ \\
\hline 39 & $17(4.4)$ & $14(9.2)$ \\
\hline 40 & $01(0.3)$ & 05 (3.3) \\
\hline Total & 230 & 153 \\
\hline
\end{tabular}

One hundred and sixty one (42\%) mothers with maternal anemia delivered low birth weight babies (Table 3).

\begin{tabular}{|l}
\hline $\begin{array}{l}\text { Table 3. Showing the effect of maternal anemia on the } \\
\text { weight of the baby. }\end{array}$ \\
$\begin{array}{lll}\text { Maternal } & \text { Weight of the baby }(\mathrm{n}=383) \\
\text { anemia } & <2.5 \mathrm{~kg}(\mathrm{LBW}) & \geq 2.5 \mathrm{~kg} \\
\text { Present } & 161(42.0) & 68(17.8) \\
\text { Absent } & 74(19.3) & 80(20.9) \\
\text { Total } & 235(61.3) & 148(38.7)\end{array}$ \\
\hline
\end{tabular}

Perinatal outcome of babies born to anemic mothers showed live born in 224 (97.4\%), low birth weight in 161 (42\%), Preterm in 130 (56.5\%), IUGR in 55 $(23.9 \%)$, NICU admission in $39(17 \%)$, anemia in baby in $14(6.1 \%)$, IUFD in $10(4.3 \%)$ and stillbirth in 2 (0.9\%) (Table 4).

Table 4. Showing the perinatal outcome of maternal anemia.

\begin{tabular}{|llc|}
\hline \multirow{2}{*}{ Characteristics } & \multicolumn{2}{l|}{ Anemia in mother(n=383) } \\
& Yes $\mathbf{n}(\%)$ & No $\mathbf{n}(\%)$ \\
Live born & $224(97.4)$ & $142(0.9)$ \\
IUFD & $10(4.3)$ & $04(2.6)$ \\
Still birth & $02(0.9)$ & $01(0.7)$ \\
IUGR & $55(23.9)$ & $15(9.8)$ \\
Low birth weight & $161(42.0)$ & $74(19.3)$ \\
$\begin{array}{l}\text { Preterm } \\
\text { Admission }\end{array}$ & $130(56.5)$ & $91(59.5)$ \\
NICU & $39(17.0)$ & $26(17.0)$ \\
$\begin{array}{l}\text { Anaemia in } \\
\text { baby }\end{array}$ & $14(6.1)$ & $11(7.2)$ \\
\hline
\end{tabular}

\section{DISCUSSION}

During the study period, 383 mothers along with their newborns were included, of which 230 (60.2\%) proportions of mothers were anemic. The prevalence of maternal anemia was found out to be $60.2 \%$ at $95 \%$ $\mathrm{Cl}(10.6-10.8 \%)$ in our study. This is similar to a study reported from India $9(60.38 \%)$ and 10 (62.3\%) while it is in contrast to some studies done in other parts of Nepal which showed a low prevalence rate ranging from 42 to $48 \% .^{11-12} \mathrm{NDHS}$ data set 2016 showed a prevalence rate of $40 \% .{ }^{13}$ Our study revealed $74.8 \%$ of mothers were moderately anemic while 58 (25.2\%) were mildly anemic. This indicates that the nutritional significance of nutrition is subordinate and awareness is made to the rectification of anemia in the pre-pregnancy period.

Our study showed mean maternal haemoglobin to be $9.5 \pm 1.76 \mathrm{gm} / \mathrm{dL}$ which is near to comparable from a study done in Nepal ${ }^{14}$ which showed the mean maternal haemoglobin concentration to be $11.14 \pm 1.39 \mathrm{gm} / \mathrm{dL}$. 
Mean maternal age in our study was a $24.24 \pm 3.26$ year which is similar to a study done by Timilsina et al. ${ }^{15}$ Mean gestational age at delivery was $36.08 \pm 1.77$ which is similar to a study done in England ${ }^{16}$ and in Nepal. ${ }^{17}$

This study showed that the maximum number of mothers $261(68.1 \%)$ were from the rural area. The percentage of low birth weight babies were more in mothers from a rural area $24.6 \%$ as compared to urban areas $13.5 \%$. This was similar to a study done by Yadav et al where $84 \%$ mothers residing in rural areas of terrain region of Nepal had a proportion of LBW in rural $21.71 \%$ and urban $20.83 \%$ areas. ${ }^{18}$

Our study showed the mean birth weight to be $2.35 \pm 0.37 \mathrm{~kg}$. Low Birth Weight was seen in 161 $(42.0 \%)$ cases of anemic mothers which is very high and is in contrary to a study done by Acharya et al which showed to be only $19.4 \%^{19}$ and $9.8 \%$ in a study done in Nepal. ${ }^{18}$ Another study showed the prevalence

to be significantly high among institutional deliveries of this region of the country.

Conflict of Interest: None.

\section{REFERENCES}

1. Debbarma R, Debbarma B, Devi MA. Effect of Maternal Anemia on Cord Hemoglobin and Birth Weight of Newborns. JDMS. 2015;14(7):19-21. [․ㅏll Text | DOI]

2. Tandon R, Jain A, Malhotra P. Management of Iron Deficiency Anemia in Pregnancy in India. Indian J Hematol Blood Transfus. 2018;34(2):204-15. [마bMed | DOI]

3. WHO. The global prevalence of anemia in 2011. Geneva: World Health Organization; 2015; 43p. [Full Text]

4. Abay A, Yalew HW, Tariku A, Gebeye E. Determinants of Prenatal Anemia in Ethiopia. Archives of Public Health. 2017;75:51. [ubMed | Full Text | DOI]

5. Ghimire N, Pandey N. Knowledge and Practice of Mothers Regarding the Prevention of Anemia during Pregnancy, in Teaching Hospital, Kathmandu. J Chitwan Med Coll. 2013;3(5):14-7. [Full Text | DOI]

6. Figueiredo ACMG, Gomes-Filho IS, Silva RB, Pereira PPS, Pereira MG et al. Maternal Anemia and Iron Deficiency Anemia: Similarities and Singularities. Health Care: Current Reviews. 2018;6(217):1-6. [ Full Text | DOI]

7. Lawani LO, Iyoke CA, Onoh RC, Nkwo PO, Ibrahim IA,Ekwedigwe KC et al. Obstetric Benefits of Health rate of $23.6 \% .^{20}$ In the present study out of the total low birth weight babies, $56.2 \%$ were males and $43.8 \%$ were female which is similar to a study done by Ahmed et $\mathrm{al}^{20}$ while it is in contrast to a study done by Hussain et al in Pakistan which showed the incidence of male $45.2 \%$ and female $55 \% .^{21}$

Our study showed mothers having preterm delivery were $23.4 \%$ and the proportion of low birth weight was high. A study from Karnataka showed the preterm birth was $38 \% .{ }^{22}$ Perinatal mortality in our study was 44.3 per thousand population which is similar to a study done $42 \% .^{23}$

\section{CONCLUSIONS}

The high prevalence rate of maternal anemia in this study implies that maternal anemia is still a public health issue which needs to be addressed in spite of the safe motherhood program launched by the government of Nepal. Low maternal haemoglobin levels are associated with increased risk of stillbirth and IUD, and LBW babies. The prevalence of low birth weight was found
Insurance: A Comparative Analysis of Obstetric Indices and Outcome of Enrollees and Non-Enrollees in southeast Nigeria. J. Obstet. Gynaecol. 2016;36:946-49. [릴ed | Full Text | DOI]

8. Charan J, Biswas T. How to calculate sample size for different study designs in medical research? Indian J Psychol Med. 2013;35(2):121-26. [Full Text | DOI]

9. Gupta A. Prevalence of maternal anemia and its impact on perinatal outcome in a rural area of Dakshina Kannada. International Journal of Medical Science and Public Health. 2016;6(7). [Full Text | DOI]

10. Suryanarayana R, Chandrappa M, Santhuram A, Prathima $\mathrm{S}$, Sheela S. Prospective study on the prevalence of anemia of pregnant women and its outcome: A community based study. J Family Med Prim Care. 2017;6(4):739-43. [PubMed | Full Text | DOI]

11. Rayamajhi N, Mishra SK, Gautam N, Doshi NR. Prevalence Of Anemia In Pregnant Women Attending a Tertiary Level Hospital in Western Region, Nepal. Journal of Universal College of Medical Sciences. 2016:4(2);17-9. [Full Text | DOI]

12. Bhandary S, Shrestha A. Prevalence of anemia among non-pregnant and pregnant women of reproductive age in Nepal. JGPEMN. 2011;2:21-6. [Full Text]

13. Rana SS, Sharma S, Chand A, Malla R. Relationship between maternal Haemoglobin and fetal weight. NJOG. 2013;8(1):37-40. [Full Text]

14. Nepal Demographic and Health Survey 2016: Key Indicators. Kathmandu, Nepal. Ministry of Health, Nepal; New ERA; 
and ICF : Ministry of Health, Nepal. 2017. [Full Text]

15. Timilsina S, Karki S, Gautam A, Bhusal P, Paudel G, Sharma D. BMC Pregnancy Childbirth. 2018;18(1):70. [PubMed | $\underline{\text { Full Text }}$ | DOI]

16. Awowole I, Cohen K, Rock J, Sparey C.Prevalence and obstetric outcome of women with red cell antibodies in pregnancy at the Leeds Teaching Hospitals NHS Trust, West Yorkshire, England. Eur J Obstet Gynaecol Reprod Biol. 2019;237:89-92. [PubMed | Full Text | DOI]

17. Kayastha P, Manandhar S. Incidence and Risk Factors of Low Birth Weight Among Babies Delivered at Tertiary Level Teaching Hospital in Nepal. MJSBH [Internet]. 2019;18(2):29-5. [Full Text | DOI]

18. Bansal P, Garg S, Upadhyay H. Prevalence of low birth weight babies and its association with socio-cultural and maternal risk factors among the institutional deliveries in Bharatpur, Nepal. Asian Journal of Medical Sciences. 2018;10(1):77-85. [Full Text $\mid \underline{\text { DOI] }}$

19. Acharya D, Singh JK, Kadel R, Yoo SJ, Park JH, Lee K. Maternal Factors and Utilization of the Antenatal Care Services during Pregnancy Associated with Low Birth Weight in Rural Nepal: Analyses of the Antenatal Care and Birth Weight Records of the MATRI-SUMAN Trial. Int J Environ Res Public Health. 2018;15(11): 2450. [PubMed | Full $\underline{\text { Text }} \mid \underline{\text { DOI] }}$
20. Ahmed S, Hassen K, Wakayo T. A health facility based case-control study on determinants of low birth weight in Dassie town, Northeast Ethiopia: the role of nutritional factors. Nutrition Journal. 2018;17(1);103. [PubMed|Full $\underline{\text { Text }} \mid \underline{\mathrm{DOI}}$

21. Hussain S, Ahmed S, Tarar S, Tasleem G. Low birth weight: frequency, demographic profile and association with maternal risk factors at a tertiary care teaching hospital. Pakistan Armed Forces Medical Journal. 2018;68(4):850-5. [Full Text]

22. Gopinath S, Dhananjaya BS, Sreelasya K, Krishna C. Prevalence of Anemia in Pregnancy and its Outcome in Rural Tertiary Care Centre in India. Indian J of Obs and Gynaecol Res. 2018;5(1):104-8. [Full Text | DOI]

23. Ghimire PR, Agho KE, Renzaho AMN, Nisha MK, Dibley M, Raynes-Greenow C. Factors Associated With Perinatal Mortality in Nepal:Evidence from Nepal Demographic and Health Survey 2001-2016. BMC Pregnancy and Childbirth. 2019;19:88. [Full Text| DOI]

\section{The Author(s) 2018.}

This work is licensed under a Creative Commons Attribution 4.0 International License. The images or other third party material in this article are included in the article's Creative Commons license, unless indicated otherwise in the credit line; if the material is not included under the Creative Commons license, users will need to obtain permission from the license holder to reproduce the material. To view a copy of this license, visit http://creativecommons.org/licenses/by/4.0/ 